\title{
The Impact of Sub Acute Administration of Purified Gambier (Uncaria gambir Roxb.) to The Liver and Kidney Functions and its Reversibility on Rats
}

\author{
Armenia*, Dita Permatasari, Lathifah Putri Sinamar, Keke Estera, Almahdy Ahmadin
}

Armenia*, Dita Permatasari, Lathifah Putri Sinamar, Keke Estera, Almahdy Ahmadin

Faculty of Pharmacy, University of Andalas, INDONESIA.

\section{Correspondence}

Armenia

Faculty of Pharmacy, University of Andalas, INDONESIA.

E-mail: armenia@phar.unand.ac.id

History

- Submission Date: 23-09-2020;

- Review completed: 26-10-2020;

- Accepted Date: 02-11-2020.

DOI : 10.5530/pj.2021.13.7

Article Available online http://www.phcogj.com/v13/11

Copyright

(C) 2021 Phcogj.Com. This is an openaccess article distributed under the terms of the Creative Commons Attribution 4.0 International license.

\begin{abstract}
Introduction: The impact of sub-acute administration of purified gambier (Uncaria gambir Roxb.) to the liver and kidney function and its reversibility had been studied on rats. Methods: Rats at the aged of 2-3 months and the bodyweight of $\pm 250 \mathrm{~g}$ were treated with water solution of purified gambier at the dose of $5 \mathrm{mg} / \mathrm{kg} 10$ and $20 \mathrm{mg} / \mathrm{kg}$ for 7 to 14 consecutive days. Plasma ALP, AST activities, creatinine clearance, liver and kidney ratios were determined on the day 1, 7, 14 one week after the doses stopped. All data on each parameter were analyzed using two-way ANOVA followed by Duncan's multiple T-test and significance was taken at $p<0.05$. Results: The results showed that all parameters was not affected significantly $(p>0.1)$, except ALT activity and liver organ ratio decreased significantly $(p<0.05)$. Conclusion: These indicated that purified gambier is relatively non-toxic to the liver and the kidney of the rats at doses of $5-20 \mathrm{mg} / \mathrm{kg} \mathrm{BW}$ for 14 days.
\end{abstract}

Key Words: Purified gambier, Liver function, Renal function, ALP, ALT, $\mathrm{CrCl}$.

\section{INTRODUCTION}

Indonesia is a country rich in flora and fauna. One of the plants that are being developed to become herbal medicinal plants is the gambier plant. This plant is spread in Aceh, North Sumatra, Riau, West Sumatra, Bangka, Belitung, and West Kalimantan. In West Sumatra this plant spreads throughout the region, such as in 50-kota, Pesisir Selatan, Tanah Datar, Pariaman, Sawahlunto, Pasaman and Solok. ${ }^{1}$

Traditionally, people have used gambier (Uncaria gambir Roxb.) to treat burned, headache diarrhea and dysentery, as a mouthwash for sore throats. Gambier extract also potential as antibacterial, antinematode, gastric ulcersreliever, antioxidants, antihypertension, prevent heart disease and hyperlipidemia. Gambier contain catechins of $7-33 \%, 20-55 \%$ of kathechu tannic acid, $20-30 \%$ of pyrocathecol, $1-3 \%$ of fluorescent gambier, $3-5 \%$ of red katechu, $2-4 \%$ of quercetin, fixed oil of $1-2 \%$, and wax of $1-2 \%$. From these chemical contents, our local government promotes the development of gambier to be to becoming a standardized herbal medicine. $^{2}$

In the contrary, in 1985 a patented drug containing catechins, namely Catergen', was withdrawn from the market due to its immunohemolysis effect to the patients. ${ }^{3}$ According to Flavonoid Pharmacokinetics Book, catechins and their metabolites at a certain dose can bind to red blood cells allowing the production of autoantibodies to cause hemolytic anemia and kidney failure. ${ }^{4}$ According to Ningsih (2017), herbal formulas contained gambier and Caesalpiniasappan extracts at doses of $300 \mathrm{mg}$ and $1200 \mathrm{mg} / \mathrm{KgBW}$ produced lesions in the liver, kidneys and heart in male and female mice, large doses indeed. ${ }^{5}$ In addition, research conducted by Takami et al reported that catechins content in green tea at a concentration of $0.5 \%$ (or equal with $3535 \mathrm{mg}$ / KgBW) reduce rat body weight and increase ALT and ALP biomarkers. ${ }^{6}$

According to WHO, a drug, include herbal medicine, not only must be effective, but also meet the safety and quality requirement. Therefore, data on the safety of herbal medicines is needed, such as data evaluation of general toxicity, specific toxicity (on certain organs) and other tests (teratogenic, carcinogenic and mutagenic tests). ${ }^{7}$

In this paper, multiple doses of purified gambier (Uncaria gambir Roxb.) toxicity to the liver and kidney functions and its reversibility will be explore.

\section{MATERIALS AND METHODS}

A number 27 male rats at the aged of 2-3 months and the body weight of $\pm 250 \mathrm{~g}$ was divided into 9 groups (3 rats per group). Group 1-3 were treated with water solution of purified gambier at the dose of $5 \mathrm{mg} / \mathrm{kg}$., group 4-6 at dose of $10 \mathrm{mg} / \mathrm{kg}$ and the last 3 group were treated at dose of 20 . Another group of 3 rats were used as control and its data was used repeatedly from day 1 to day 21 . The gambier was given orally once a day for 14 days. During the experimental period, the animals were fed and drunk ad libitum, 24 hourly urine output was collected, measured to determine the urine creatinine and specific gravity. Three of the rats were killed and the blood sample and the liver and kidney were taken to measure the ALP, AST activities, creatinine plasma, liver and kidney ratios respectively on the day $1,7,14$ and 21. Urine and plasma creatinine was determine using creatinine kit (Greiner ${ }^{\circledR}$ ), while AST and 
ALP activities were determined using ALT KIT DiaSys ${ }^{\bullet}$ and Alkaline phosphatase KIT DiaSys respectively. All of these three parameters were measured by photometer (Photometer $5010 \mathrm{~V} 5+$ ). The creatinine clearance, the liver and kidney ratioswere then calculated. All data on each parameter were analyzed using two-way ANOVA followed by Duncan's multiple T-test and significance was taken at $\mathrm{P}<0.05$. For the experimental, the ethics code approval of the was obtained from ethics committee of the Faculty of Medicine, Andalas University, Padang Indonesia (The registration numbers are 156/KEP/FK/2020 and 159/ $\mathrm{KEP} / \mathrm{FK} / 2020$ ).

\section{RESULTS}

Animal ALT activity was significantly decreased by the doses $(\mathrm{p}<0.05)$ and duration $(\mathrm{p}<0.05)$ of purified gambier administration but not by the interaction of these two variables $(\mathrm{p}>0.1)$. However, ALT activity remain unchanged after gambier was stopped. The averages of ALT activities of the animal on the day $1,8,15$ and 22 were $150.333 \pm 10.4$; $93.5 \pm 10.4 ; 99.3 \pm 10.4 ; 108.2 \pm 10.4$ while the averages of animal ALT activities of control group and the group treated with gambier at doses of 5,10 , and $20 \mathrm{mg} / \mathrm{KgBW}$ were $150.3 \pm 10.4 ; 104.0 \pm 10.4 ; 97.0 \pm 10.4$ ; $100.0 \pm 10.4$ respectively. There was no significant responses between doses and duration of administration (Table 1 and Figure 1).
The data showed that the ALT activities of all animals are in the normal ranges (52-224 IU/L) (52).

On the other hands, animal ALP activities did not significantly affected by the doses and duration of purified gambier administration nor the interaction of these two variables ( $p>0.1)$ (Table 2 and Figure 2). The averages of animal ALP activities on day 1, 8, 15, dan 22 were $221.3 \pm$ $27.0 ; 242.7 \pm 27.0 ; 204.7 \pm 28.7$ and $221.7 \pm 28.7 \mathrm{IU} / \mathrm{L}$ and the animal ALP activities of control and the animal treated with purified gambier at doses of 5, 10, and $20 \mathrm{mg} / \mathrm{KgBW}$ were $221.3 \pm 27.0 ; 224.2 \pm 28.7$; $199.9 \pm 27.0$ and $245.1 \pm 28.7 \mathrm{IU} / \mathrm{L}$ (Table 2 and Figure 2).

From the above data we can see that these numbers are still in a normal range, even though those in the animal treated with purified gambier at dose of $20 \mathrm{mg} / \mathrm{kg} \mathrm{BW}$ for 8-14 days, the level is a bit higher and remain higher even 7 days after gambier administration had been stopped. Actually, the normal ALP activity is vary, depends on the animal age. In his study, we use rats at the age of $8-10$ weeks. During this period, ALP activity is higher, as reported by Hoffmann et al., (1994) was of 343 - $353 \mathrm{IU} / \mathrm{L}$ in female and more higher in male $(>500 \mathrm{IU} / \mathrm{L}){ }^{8}$

The animal liver ratio was significantlyaffected by purified gambier dose and duration of administration $(\mathrm{p}<0.05)$ but not by interaction of these two variables $(p>0.1)$. The liver ratio of animal treated with gambier

Table 1: The impact doses and duration of administration and after stopping of purified gambier to the rat ALT activities.

\begin{tabular}{|c|c|c|c|c|c|}
\hline \multirow{2}{*}{$\begin{array}{c}\text { Doses } \\
(\mathrm{mg} / \mathrm{Kg} \mathrm{BW})\end{array}$} & \multicolumn{4}{|c|}{ The averages ALT activities (IU/L) on days \pm SE } & \multirow{2}{*}{ Averages $\pm \mathrm{SE}$} \\
\hline & 1 & 7 & 14 & 21 & \\
\hline Control & $150.3 \pm 20.9$ & $150.3 \pm 20.9$ & $150.3 \pm 20.9$ & $150.3 \pm 20.9$ & $150.3 \pm 10.4^{q}$ \\
\hline 5 & $150.3 \pm 20.9$ & $78.3 \pm 20.9$ & $74.0 \pm 20.9$ & $113.6 \pm 20.9$ & $104.0 \pm 10.4^{\mathrm{p}}$ \\
\hline 10 & $150.3 \pm 20.9$ & $69.6 \pm 20.9$ & $69.3 \pm 20.9$ & $98.6 \pm 20.9$ & $97.0 \pm 10.4^{p}$ \\
\hline 20 & $150.3 \pm 20.9$ & $75.6 \pm 20.9$ & $103.6 \pm 20.9$ & $70.3 \pm 20.9$ & $100.0 \pm 10.4^{\mathrm{p}}$ \\
\hline Averages \pm SE & $150.3 \pm 10.4^{\mathrm{b}}$ & $93.5 \pm 10.4^{\mathrm{a}}$ & $99.3 \pm 10.4^{\mathrm{a}}$ & $108.2 \pm 10.4^{\mathrm{a}}$ & \\
\hline
\end{tabular}

Table 2: The impact doses and duration of administration and after stopping of purified gambier to the rat ALP activities.

\begin{tabular}{|c|c|c|c|c|c|}
\hline \multirow{2}{*}{$\begin{array}{c}\text { Doses } \\
(\mathrm{mg} / \mathrm{Kg} \mathrm{BW})\end{array}$} & \multicolumn{4}{|c|}{ The averages ALP activities (IU/L) on days \pm SE } & \multirow{2}{*}{ Averages $\pm \mathrm{SE}$} \\
\hline & 1 & 7 & 14 & 21 & \\
\hline Control & $221.3 \pm 54.1$ & $221.3 \pm 54.1$ & $221.3 \pm 54.1$ & $221.3 \pm 54.1$ & $221.3 \pm 27.0$ \\
\hline 5 & $221.3 \pm 54.1$ & $288.0 \pm 54.1$ & $189.0 \pm 54.1$ & $198.5 \pm 66.3$ & $224.2 \pm 28.7$ \\
\hline 10 & $221.3 \pm 54.1$ & $205.3 \pm 54.1$ & $169.3 \pm 54.1$ & $203.6 \pm 54.1$ & $199.9 \pm 27.0$ \\
\hline 20 & $221.3 \pm 54.1$ & $256.3 \pm 54.1$ & $239.0 \pm 66.3$ & $263.3 \pm 54.1$ & $245.1 \pm 28.7$ \\
\hline Averages $\pm \mathrm{SE}$ & $221.3 \pm 27.0$ & $242.7 \pm 27.0$ & $204.7 \pm 28.7$ & $221.7 \pm 28.7$ & \\
\hline
\end{tabular}

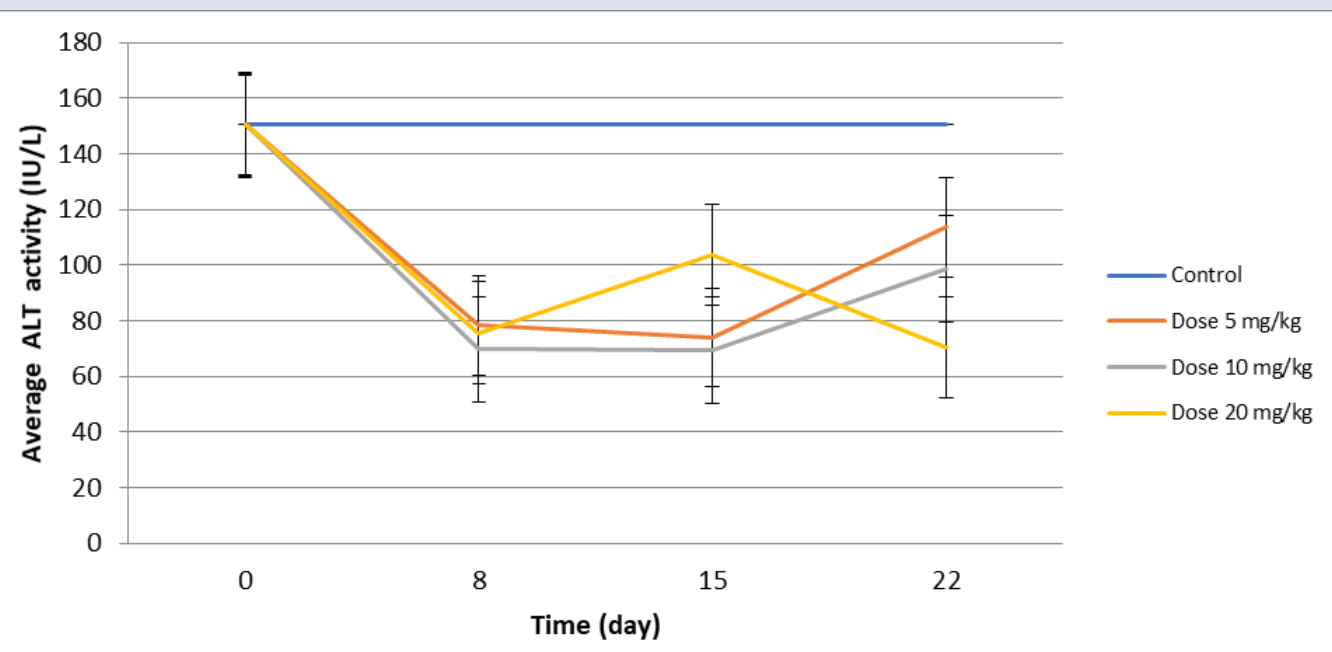

Figure 1: The impact doses and duration of administration and after stopping of purified gambier to the rat ALT activities. 
was lower compared to that of control group, especially after treated for 7 - 14 days. However, most of the animal showed increases in the liver ratio after gambier administration was stopped. The averages liver ratio of the animals on the day $0,8,15$ and 22 were $0.042 \pm 0.001 ; 0.037 \pm$ $0.001 ; 0.034 \pm 0.001$ and $0.040 \pm 0.001$ and this averages ratio of control animal and the animal treated with purified gambier at the doses of 5, 10 and $20 \mathrm{mg} / \mathrm{KgBW}$ were $0.042 \pm 0.001 ; 0.038 \pm 0.001 ; 0.037 \pm 0.001$ and $0.037 \pm 0.001$ respectively (Table 3 and Figure 3 ).

Creatinine clearance (CCr) of the animals was not significantly affected by administration of purified gambier based on dose $(p>0.1)$ nor by duration of administration ( $p>0.1)$ or interaction of both variables ( $>0.1)$. This stand to reason not change the renal function significantly (Table 4 and Figure 4), The averages of renal CCr of the control animals and the animal treated with the purified gambier at doses of 5, 10 and $20 \mathrm{mg} / \mathrm{kgBW}$ were $0.103 \pm 0.029 ; 0.135 \pm 0.029 ; 0.115 \pm 0.029$ and 0.122 $\pm 0.029 \mathrm{~mL} / \mathrm{min}$ while the averages of renal CCr on day $1,7,15$ and 22 were $0.103 \pm 0.029 ; 0.095 \pm 0.029 ; 0.106 \pm 0.029$ and $0.172 \pm 0.029 \mathrm{ml} /$ $\min$.
Kidney ratio of the animal did not significantly affected by the dose and duration of purified gambier administration and the interaction of these two variables $(p>0.1)$. The averages of kidney ratio of control animals and the animals treated with gambier at doses of 5, 10 dan 20 $\mathrm{mg} / \mathrm{kg} \mathrm{BW}$ were $0.007562 \pm 0.000174 ; 0.007987 \pm 0.000174 ; 0.007455$ \pm 0.000174 and $0.007565 \pm 0.000174$, while the averages ratio of this organ on day $1,8,15$ and 22 were $0.007562 \pm 0.0174 ; 0.7661 \pm 0.0174$; $0.779 \pm 0.0174$ and $0.7555 \pm 0.0174$ (Table 5 and Figure 5)

\section{DISCUSSION}

Alanine aminotransferase (ALT ) and alkaline phosphatase (ALP) are among the main parameters for determining the liver function that were used in this study. ${ }^{9,10}$ ALT is also referred to as glutamate: pyruvate aminotransferase (GPT), is a pyridoxal59-phosphate (PLP) enzyme that catalyzes the reversible transfer of the amino group of alanine to 2-oxoglutarate to form glutamate and pyruvate. ${ }^{11}$ ALT levels are very useful in diagnosing liver damage. ${ }^{12}$ ALP is an enzyme biomarker for monitoring the integrity and damage to liver structures and helps in

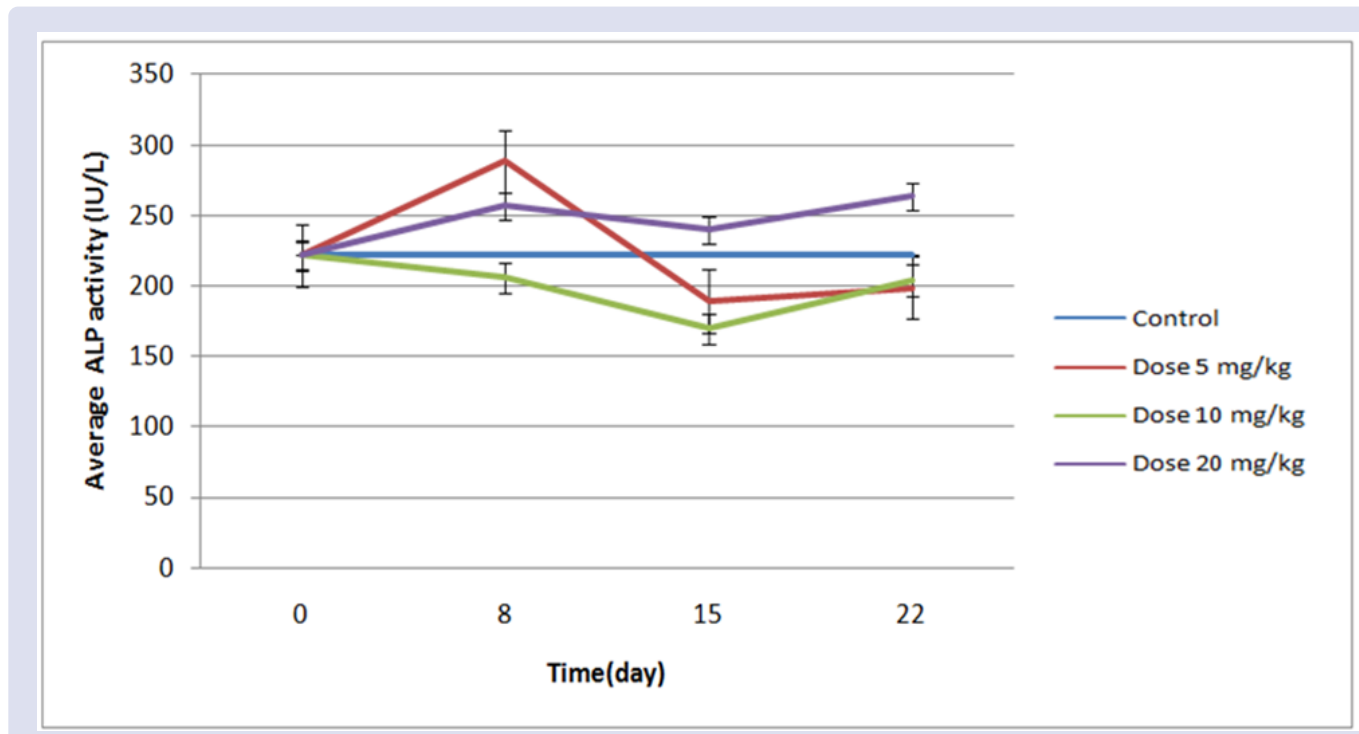

Figure 2: The impact doses and duration of administration and after stopping of purified gambier to the rat ALP activities.

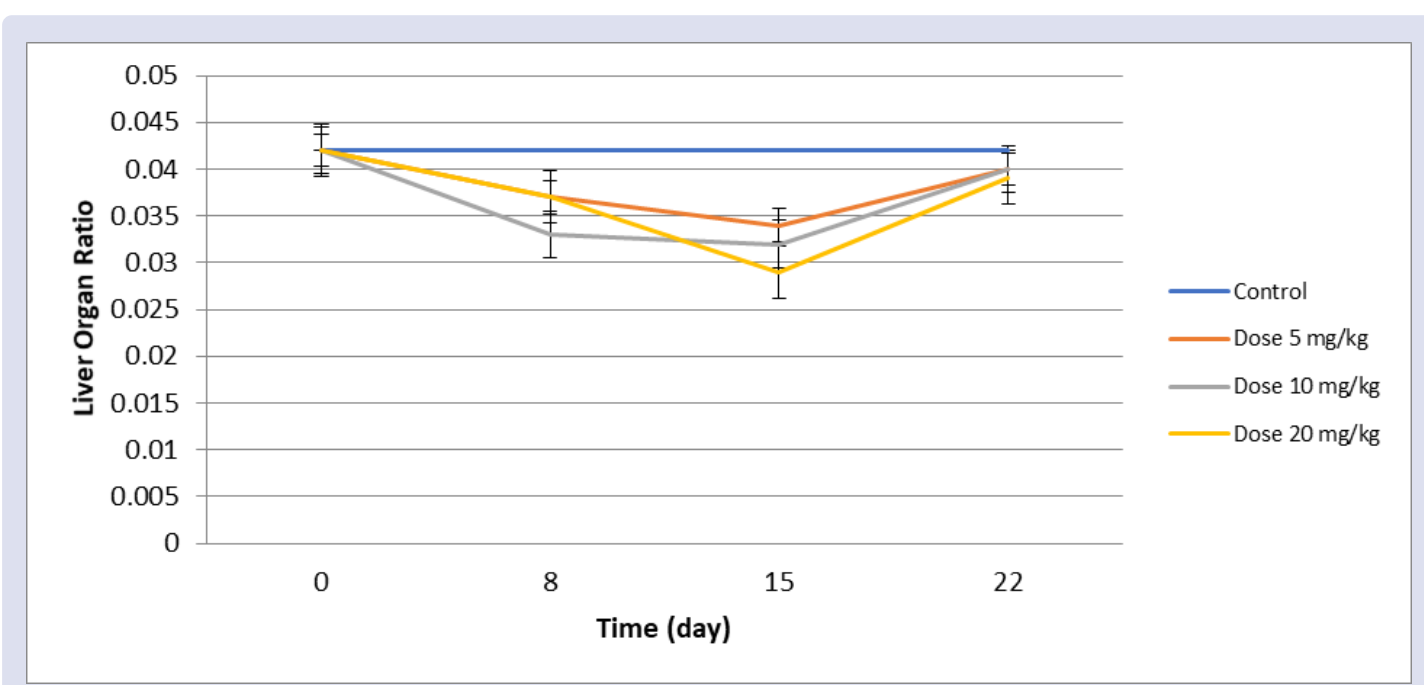

Figure 3: The impact of doses and duration of administration and after stopping purified gambier to the rat liver ratio. 


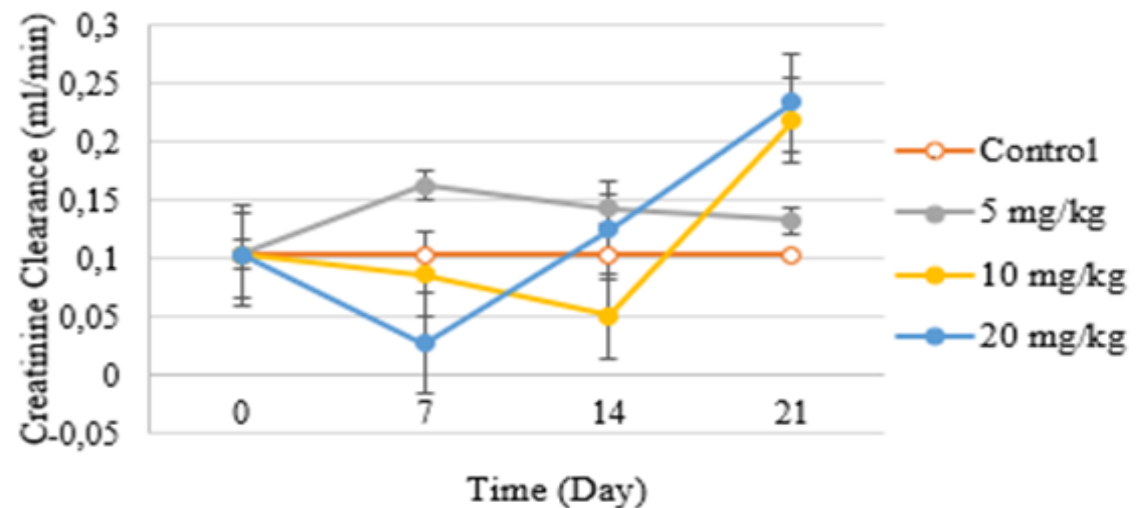

Figure 4: The impact of doses and duration of administration and after stopping purified gambier to the rat renal creatinine clearance.

Table 3: The impact of doses and duration of administration and after stopping purified gambier to the rat liver ratio.

\begin{tabular}{|c|c|c|c|c|c|}
\hline \multirow{2}{*}{$\begin{array}{c}\text { Doses } \\
(\mathrm{mg} / \mathrm{Kg} \mathrm{BW})\end{array}$} & \multicolumn{4}{|c|}{ Averages liver ratio $\left(x 10^{-2}\right) \pm S E$ on day } & \multirow{2}{*}{ Averages $\pm \mathrm{SE}$} \\
\hline & 1 & 7 & 14 & 21 & \\
\hline Control & $4,2 \pm 0,2$ & $4,2 \pm 0,2$ & $4,2 \pm 0,2$ & $4,2 \pm 0,2$ & $4,2 \pm 0,1^{\mathrm{q}}$ \\
\hline 5 & $4,2 \pm 0,2$ & $3,7 \pm 0,2$ & $3,4 \pm 0,2$ & $4 \pm 0,2$ & $3,8 \pm 0,1^{p}$ \\
\hline 10 & $4,2 \pm 0,2$ & $3,3 \pm 0,2$ & $3,2 \pm 0,2$ & $4 \pm 0,2$ & $3,7 \pm 0,1^{p}$ \\
\hline 20 & $4,2 \pm 0,2$ & $3,7 \pm 0,2$ & $2,9 \pm 0,2$ & $3,9 \pm 0,2$ & $3,7 \pm 0,1^{p}$ \\
\hline Averages \pm SE & $4,2 \pm 0,1^{\mathrm{c}}$ & $3,7 \pm 0,1^{b}$ & $3,4 \pm 0,1^{\mathrm{a}}$ & $4.0 \pm 0,1^{\mathrm{c}}$ & \\
\hline
\end{tabular}

Table 4: The impact of doses and duration of administration and after stopping purified gambier to the rat renal creatinine clearance.

\begin{tabular}{|c|c|c|c|c|c|}
\hline \multirow{2}{*}{$\begin{array}{l}\text { Doses } \\
\text { (mg/Kg BW) }\end{array}$} & \multicolumn{4}{|c|}{ Averages renal $\mathrm{CCr}(\mathrm{mL} / \mathrm{min}) \pm \mathrm{SE}$ on day } & \multirow{2}{*}{ Averages $\pm \mathrm{SE}$} \\
\hline & 1 & 7 & 14 & 21 & \\
\hline Control & $0.103 \pm 0.059$ & $0.103 \pm 0.059$ & $0.103 \pm 0.059$ & $0.103 \pm 0.059$ & $0.103 \pm 0.029$ \\
\hline 5 & $0.103 \pm 0.059$ & $0.162 \pm 0.059$ & $0.143 \pm 0.059$ & $0.132 \pm 0.059$ & $0.135 \pm 0.029$ \\
\hline 10 & $0.103 \pm 0.059$ & $0.086 \pm 0.059$ & $0.051 \pm 0.059$ & $0.218 \pm 0.059$ & $0.115 \pm 0.029$ \\
\hline 20 & $0.103 \pm 0.059$ & $0.028 \pm 0.059$ & $0.125 \pm 0.059$ & $0.233 \pm 0.059$ & $0.122 \pm 0.029$ \\
\hline Averages $\pm \mathrm{SE}$ & $0.103 \pm 0.029$ & $0.095 \pm 0.029$ & $0.106 \pm 0.029$ & $0.172 \pm 0.029$ & \\
\hline
\end{tabular}

Table 5: The impact of doses and duration of administration and after stopping purified gambier to the rat renal ratio.

\begin{tabular}{|c|c|c|c|c|c|}
\hline \multirow{2}{*}{$\begin{array}{c}\text { Doses } \\
(\mathrm{mg} / \mathrm{Kg} \mathrm{BW})\end{array}$} & \multicolumn{4}{|c|}{ Average renal ratio $\left(\times 10^{-2}\right) \pm \mathrm{SE}$ on day } & \multirow{2}{*}{$\begin{array}{c}\text { Averages } \\
\left(\times 10^{-2}\right) \pm S E\end{array}$} \\
\hline & 1 & 7 & 14 & 21 & \\
\hline Control & $0.7562 \pm 0.0349$ & $0.7562 \pm 0.0349$ & $0.7562 \pm 0.0349$ & $0.7562 \pm 0.0349$ & $0.7562 \pm 0.0174$ \\
\hline 5 & $0.7562 \pm 0.0349$ & $0.7679 \pm 0.0349$ & $0.8530 \pm 0.0349$ & $0.8177 \pm 0.0349$ & $0.7987 \pm 0.0174$ \\
\hline 10 & $0.7562 \pm 0.0349$ & $0.7454 \pm 0.0349$ & $0.7475 \pm 0.0349$ & $0.7328 \pm 0.0349$ & $0.7455 \pm 0.0174$ \\
\hline 20 & $0.7562 \pm 0.0349$ & $0.7950 \pm 0.0349$ & $0.7594 \pm 0.0349$ & $0.7153 \pm 0.0349$ & $0.7565 \pm 0.0174$ \\
\hline Averages \pm SE & $0.7562 \pm 0.0174$ & $0.7661 \pm 0.0174$ & $0.7790 \pm 0.0174$ & $0.7555 \pm 0.0174$ & \\
\hline
\end{tabular}




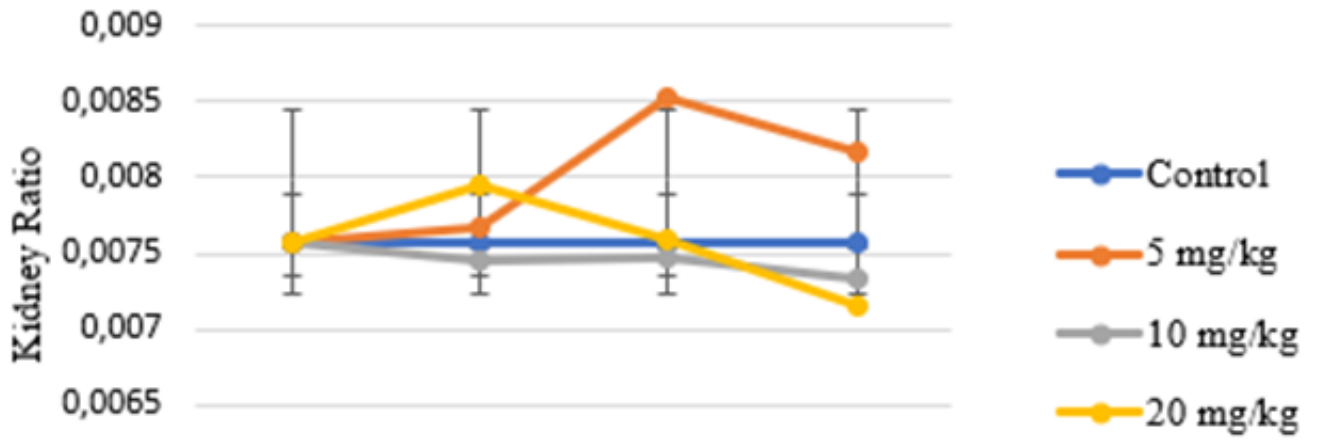

0,006

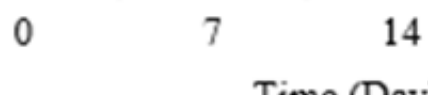

21

Figure 5: The impact of doses before, during and one week after administration of the purified gambier was stopped to the rat kidney ratio

the clinical diagnosis of liver toxicity conditions. ${ }^{10}$ ALP activity also is routinely determined in most toxicological studies involving mice. This enzyme is found histochemical in the bile microvilli of the canaliculi and on the sinusoidal surface of hepatocytes. ${ }^{13}$

Data showed that animals treated with purified gambier had lower ALT activity values compared to that of control. This indicated that the purified gambier is not toxic to the liver. It rather protect the liver from the damage. This is agreement with a previous study, whom reported that the catechin content of gambier (a flavonoid) an active substanceis potential as antioxidant and hepato-protector. ${ }^{14}$ Indeed, normal value of ALT activity in this study is quite higher compared to those reported elsewhere. ${ }^{10,15,16}$ But this still in the common range value in rat (52-224 IU/L). ${ }^{9}$

This data is supported by serum ALP activity, in this study which not significantly changed under purified gambier treatment. ALP is a marker enzyme for the plasma membrane and endoplasmic reticulum. ALP is often used to assess the integrity of the plasma membrane, so that if the ALP value is high in the tissue and serum it indicates possible damage to external cells (plasma membrane). Elevated in ALP levels are likely a manifestation of membrane damage because ALP is a membrane-bound enzyme. High levels of serum ALP activity are commonly seen in liver damage, cancer, and heart infections. High levels of serum ALP activity are commonly seen in liver damage, cancer, and heart infections. ${ }^{17}$ Even though serum ALP activity in this study is much higher than some reported previously, ${ }^{10,15,16}$ but is in agree with Hoffmann (1994) where the ALP activity may vary with age, sex, and breastfeeding. In this study, we used the $8-10$ week age rat, where the ALP activity values is highest compare to the other ages. ${ }^{8}$

In the other hand, animal liver ratios under gambier treatment animal was lower compared with control, but the ratio was returned to normal one week after gambier was stopped. The differences in body weights are often accompanied by differences organ ratio. This made more difficult to interpret the data of this parameter. ${ }^{18}$ That's why organ ratio parameter cannot be used as the main parameter in assessing liver function but is only used as supporting data. In this study the liver organ ratio decreased due to the increase in animal body weight during the testing period. To approve the damage of the liver tissue based on the liver ratio data, histologically assessment should be studied further.

From the above explanations, it is indicated that purified gambier is relatively non-toxic to the liver function of white rats. This is evidenced by the value of the ALT, ALP and liver ratio. These results is in agreement with Bachtiar, whose reported that gambier and gambier's properties is hepatoprotector, ${ }^{3}$ and so as with one reported by Evi Ainun Fitrianingsih (2019). ${ }^{19}$

Furthermore, similar result is also found in the renal data, where there was no significant change in the value of creatinine clearance and the percentage of renal function of the gambier treated rats compared to the control group. All treated animals in each group had normal kidney function (>90\%). This data is supported by an unchanged kidney ratio showed in this study. Catechins content of gambier plays a role in reducing oxidative stress, and prevent liver and kidneys damage. ${ }^{20}$ Our previous study also showed that gambier prolong the animal death from the renal damage induced by glycerol. ${ }^{21}$ Further study on liver and kidney histopathology is still on going.

\section{CONCLUSION}

From this study we can concluded that purified gambier is relatively safe to the liver and kidney when it is used for 14 consecutive days.

\section{ACKNOWLEDGEMENT}

This research is sponsored by the Research Grant of Faculty of Pharmacy of Universitas Andalas in 2020 with contract number is 10/un16.10.D/ pj.01./2020.

\section{REFERENCES}

1. Fauza H. Pengembangan Usaha Perkebunan dan Industri Gambir, di Sumatra Barat: Peluang dan Tantangan (Gambir Plantation and Industrial Business Development, West Sumatra: Opportunities and Challenges). In: Seminar Nasional: Reformasi Pertanian Terintegrasi Menuju Kedaulatan Pangan. Bangkalan - Jawa Timur; 2011;1-8

2. Isnawati $A$, Raini M, Sampurno OD, D.Mutiatikum, Widowati L, Gitawati $R$. Karakterisasi Tiga Jenis Ekstrak Gambir (Uncaria gambir Roxb) dari Sumatra Barat (Characterization of Three Types of Gambir Extract (Uncaria gambir Roxb) from West Sumatra). Bull Penelit Kesehat. 2012;40(4):201-8. 
3. Hasti S, Muchtar H, Bakhtia A. Uji Aktivitas Hepatoproteksi dan Toksisitas Akut dari Ekstrak Gambir Terstandarisasi (Hepatoprotection Activity and Acute Toxicity Test of Standardized Gambir Extract). J Penelit Farm Indones. 2012;1(Septembern2012):34-8.

4. Martinez SE, Davies NM, Reynolds JK. Toxicology and Safety of Flavonoids. In: Davies NM, Yanez JA, editors. Flavonoid Pharmacokinetics: Methods of Analysis, Preclinical and Clinical Pharmacokinetics, Safety, and Toxicology. First Edit. Canada: John Wiley \& Sons, Inc.; 2013;249-80.

5. Ningsih S, Agustini K, Nizar, Damayanti R. Uji Toksisitas Subkronik Kombinas Ekstrak Daun Uncaria gambir dan Caesalpinia sappan (Sub-chronic Toxicity Test of Uncaria gambir and Caesalpinia sappan Combined Extract). Kefarmasian Indones. 2017;7(1):34-45

6. Takami S, Imai T, Hasumura M, Cho YM, Onose J, Hirose M. Evaluation of toxicity of green tea catechins with 90-day dietary administration to F344 rats. Food Chem Toxicol. 2008;46(6):2224-9.

7. Yuliandra Y, Armenia N, Salasa AN, Ismed F. Subchronic toxicity of ethanolic extract of Cassytha filiformis L. on the renal function of rat. J Sains Farm Klin. 2015;2(1):54-9.

8. Hoffmann WE, Everds N, Pignatello M, Solter PF. Automated and semiautomated analysis of rat alkaline phosphatase isoenzymes. Toxicol Pathol. 1994;22(6):633-8

9. Suckow MA, Schroeder V, Douglas FA. Important Biological Features. Lab Rabbit. 2020;17-26

10. 1Hasan KMM, Tamanna N, Haque MA. Biochemical and histopathological profiling of Wistar rat treated with Brassica napus as a supplementary feed. Food Sci Hum Wellness [Internet]. 2018;7(1):77-82.

11. $1 \mathrm{McAllister} \mathrm{CH}$, Facette $\mathrm{M}$, Holt $\mathrm{A}$, Good AG. Analysis of the Enzymatic Properties of a Broad Family of Alanine Aminotransferases. PLoS One. 2013;8(2).

12. 1 Huang $X J$, Choi $Y K, I m$ HS, Yarimaga O, Yoon E, Kim HS. Aspartate aminotransferase (AST/GOT) and alanine aminotransferase (ALT/GPT) detection techniques. Sensors. 2006;6(7):756-82.
13. 1Kushwaha VB, Maurya S. Variation In Acid And Alkaline Phosphatase Activity In The Liver Of Albino Rats On Exposure To Sub Lethal Concentration Of Ethanolic Extract Of Parthenium Hysterophorus. 2012:4(8):17-20.

14. 1Taria SA, Rita RS, Afriwardi. The Effect of Gambir' s Catechin Isolate (Uncaria Gambir Roxb.) on Alanine Aminotransferase and Aspartate Aminotransferase Serum Level at Male Rats (Rattus norvegicus) Wistar Strain Induced by High Fat Diet. Int J Res Rev. 2020;7(March):488-94

15. 1Yakubu OE, Olawale O, Arowora K. Biochemical Changes in Haematological and Liver Function Parameters in Intoxicated Male Albino Rats Treated with Hymenocardia acida Leaves Ethanolic Extract. Insights Biomed. 2017;02(02):1

16. 1 George BO, Osioma E, Okpoghono J, Aina OO. Changes in liver and serum transaminases and alkaline phosphatase enzyme activities in Plasmodium berghei infected mice treated with aqueous extract of Aframomum sceptrum. African J Biochem Res [Internet]. 2011;5(9):277-81.

17. 1 Adeyemi OT, Osilesi O, O. Adebawo O, D. Onajobi F, Oyedemi SO, Afolayan AJ. Alkaline Phosphatase (ALP), Aspartate Aminotransferase (AST) and Alanine Aminotransferase (ALT) Activities in Selected Tissues of Rats Fed on Processed Atlantic Horse Mackerel (\&lt;i\&gt;Trachurus trachurus\&lt;/i\&gt;). Adv Biosci Biotechnol. 2015;06(03):139-52.

18. 1 Nirogi R, Goyal V, Jana S, Pandey SK, Gothi A. What Suits Best For Organ Weight Analysis: Review Of Relationship Between Organ Weight And Body / Brain Weight For Rodent Toxicity Studies. In 2014.

19. 1Fitrianingsih EA. Uji Toksisitas Akut Oral Isolat Katekin Gambir (Uncaria Gambier Roxb.) pada Mencit Putih Betina Swiss Webster Dengan Menggunakan Metode Standar Oecd 425 Up And Down Procedure (Acute Oral Toxicity Test of Gambir Catechin Isolate (Uncaria Gambier Roxb.) in Sw [Internet]. Sekolah Tinggi Farmasi Indonesia; 2019

20. 2Pane YS, Ganie RA, Lindarto D, Lelo A. The effect of gambier extract on the levels of malondialdehyde, superoxide dismutase, and blood glucose in type 2 diabetes mellitus patients. Asian J Pharm Clin Res. 2018;11(10):121-4.

21. 2Yona HP. Pengaruh Pemberian Gambir Terstandardisasi Terhadapfisiologis Ginjal Tikus Yang Gagal Ginjal. In 2013. 


\section{GRAPHICAL ABSTRACT}
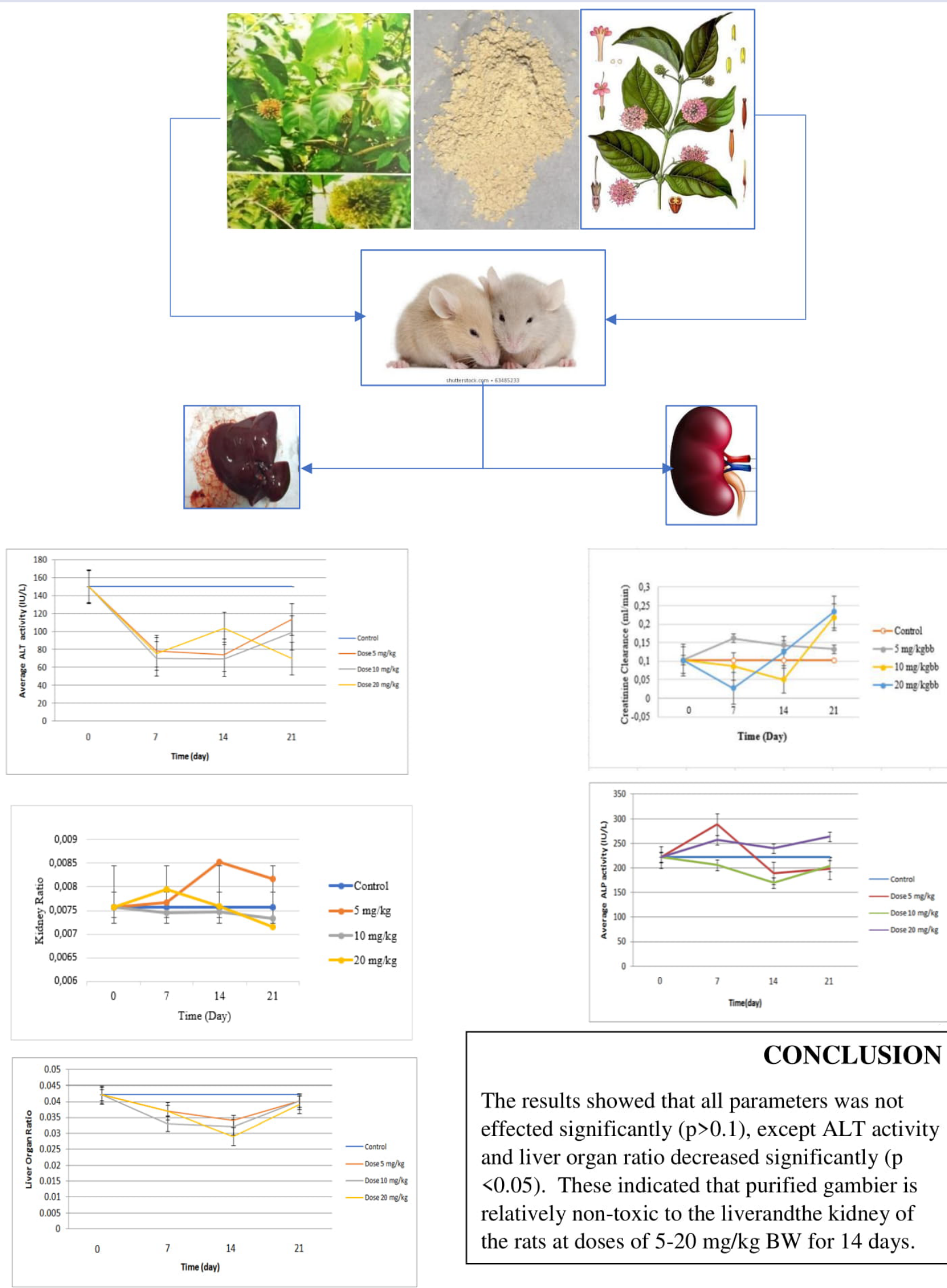

CONCLUSION

The results showed that all parameters was not effected significantly ( $p>0.1$ ), except ALT activity and liver organ ratio decreased significantly ( $\mathrm{p}$ $<0.05$ ). These indicated that purified gambier is relatively non-toxic to the liverandthe kidney of the rats at doses of $5-20 \mathrm{mg} / \mathrm{kg} \mathrm{BW}$ for 14 days. 


\section{ABOUT AUTHORS}

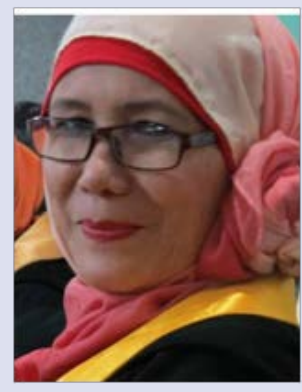

Prof. Armenia, MS, PhD. Apt.: is a professor in Physiology and Pharmacology since 2009. She got her Bachelor degree from the Dept. of Pharmacy, Faculty of Mathematic and Natural Sciences $1 \mathrm{n}$ 1985, and a year later she got her professional Apotheker degree from the same dept.. In 1990 she graduated for her master in pharmacology at Bandung Institute of Technology and in 2001 she graduated for her $\mathrm{PhD}$ at the University of Malaysia.

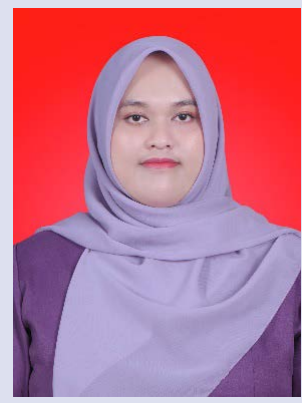

Dita Permatasari, M.Farm., Apt.: Currently a lecturer at the Faculty of Pharmacy, Andalas University. Graduated from the Faculty of Pharmacy, Andalas University for Bachelor degree in 2013, and a year later got her professional Apotheker degree in 2014, then the Master's Program in 2017. Currently working as a lecturer in Pharmacology and Clinical Pharmacy at the Faculty of Pharmacy, Andalas University.

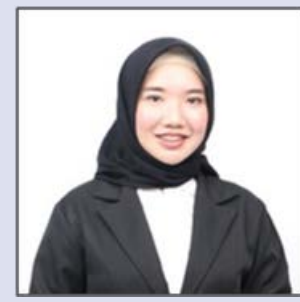

Lathifah Putri Sinamar, S.Farm.: She is a student at the Faculty of Pharmacy, Andalas University, who has been involved in research that studies the sub-acute toxicity of purified gambier (Uncaria gambir Roxb.) on rat kidney function.

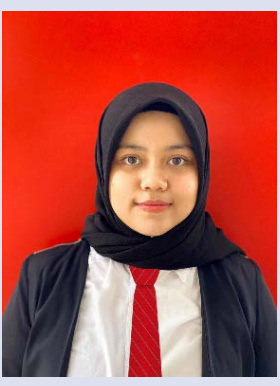

Keke Estera, S.Farm.: She is a pharmacy student from Andalas University. She has been involved in a sub-acute toxicity study of Uncaria gambir to the liver function of white rats.

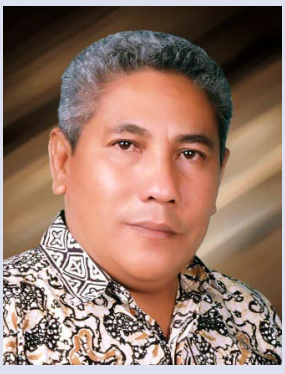

Prof. Dr. Almahdy A., M.Si., Apt.: is a senior lecturer of Pharmacy Andalas University. Graduated from the Faculty of Pharmacy, Andalas University in 1985, then the Master's Program in 1990 at the Bandung Institute of Technology School of Pharmacy (ITB) and the Doctoral Program at Andalas University in 2006. Interest in pharmacology and toxicolgy as many reseaches he has conducted with colaborative with some colleages in pharmacy andalas university and other universities.

Cite this article: Armenia, Permatasari D, Sinamar LP, Estera K, Ahmadin A. The Impact of Sub Acute Administration of Purified Gambier (Uncaria gambir Roxb.) to The Liver and Kidney Functions and its Reversibility on Rats. Pharmacog J. 2021;13(1): 44-51. 